\title{
Chad: Financial Sector Stability Assessment
}

This financial sector stability assessment on Chad was prepared by a staff team of the International Monetary Fund as background documentation for the periodic consultation with the member country. It is based on the information available at the time it was completed on August 23, 2011. The views expressed in this document are those of the staff team and do not necessarily reflect the views of the government of Chad or the Executive Board of the IMF.

The policy of publication of staff reports and other documents by the IMF allows for the deletion of market-sensitive information.

Copies of this report are available to the public from

International Monetary Fund • Publication Services

$70019^{\text {th }}$ Street, N.W. • Washington, D.C. 20431

Telephone: (202) 623-7430 • Telefax: (202) 623-7201

E-mail: publications@imf.org Internet: http://www.imf.org

\section{International Monetary Fund Washington, D.C.}




\title{
INTERNATIONAL MONETARY FUND
}

\section{CHAD}

\section{Financial System Stability Assessment}

\section{Prepared by the Monetary and Capital Markets and African Department Departments}

\author{
Approved by José Viñals and Antoinette M. Sayeh
}

August 23, 2011

This Financial System Stability Assessment (FSSA) is based on the work of a joint International Monetary Fund (IMF) - World Bank Financial Sector Assessment Program (FSAP) mission to Chad during May 25-June 10, 2011. It draws upon the 2006 Central African Economic and Monetary Community (CEMAC) regional FSAP. The FSAP team comprised Messrs. Prosper A. Youm (Mission Chief, IMF), Djibrilla A. Issa (Mission Chief, World Bank), Hong Wang, Samer Saab, Kayoung Chung (all IMF), Magueye Dia, Lionel Yondo, Olivier Hassler, Guillaume Gilkes, and Ms. Paulette Zoua (all World Bank), Messrs. Bernard Sivan and Baudouin Richard (IMF experts), and André Ryba (World Bank expert).

The FSAP team's main findings are:

- The banking system is highly vulnerable to risks stemming from the large exposure to government and government contractors, and to basic commodity export markets.

- Bank portfolios are extremely concentrated with all banks breaching the single large exposure limit. Banks need to raise capital to participate in financing of large projects.

- $\quad$ Establishing a regular issuance calendar for treasury bills would help eliminate payments delays and contribute to the development of the nascent regional public debt market.

- $\quad$ The management of the two pension funds needs to be improved significantly, starting with an actuarial review.

- $\quad$ The government's heavy presence in banks has resulted in management inefficiencies and has caused the resolution of troubled institutions to become protracted.

The main author of this report is Prosper Youm, with contributions from Kayoung Chung, Samer Saab, and other members of the FSAP team.

FSAP assessments are designed to assess the stability of the financial system as a whole and not that of individual institutions. They have been developed to help countries identify and remedy weaknesses in their financial sector structure, thereby enhancing their resilience to macroeconomic shocks and crossborder contagion. FSAP assessments do not cover risks that are specific to individual institutions such as asset quality, operational or legal risks, or fraud. 
Glossary 3

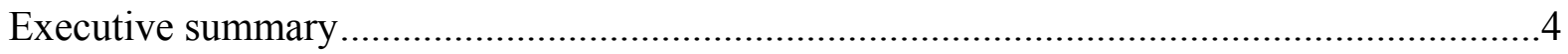

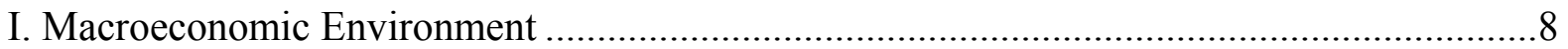

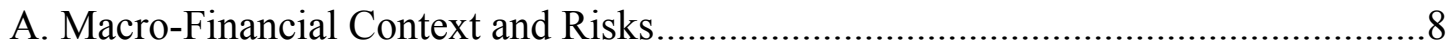

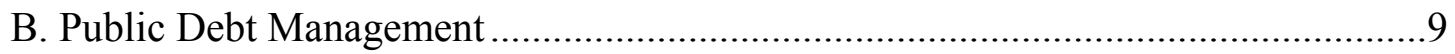

II. Structure of the Financial Sector and Vulnerabilities ................................................... 10

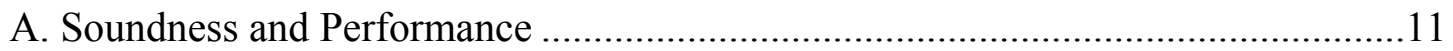

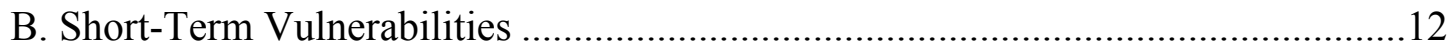

C. Supervision and Crisis Management..............................................................13

III. Strengthening Financial Sector Intermediation ........................................................ 14

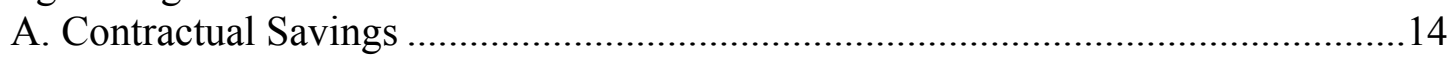

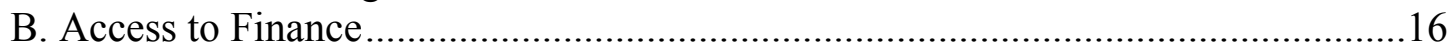

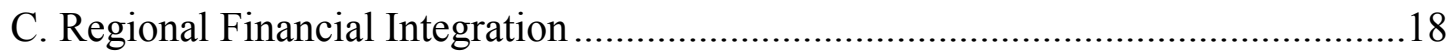

Tables

D. Legal and Judicial Environment for Lending ..................................................19

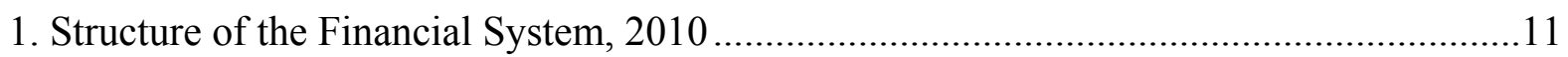

2. State-Owned Banks Vs. Foreign Private Banks Soundness Indicators .............................. 12

3. Macroeconomic and Financial Indicators $(2009-16)$..................................................23

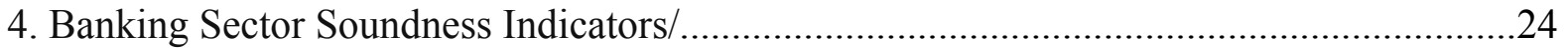

5. Stress Test —Credit Risk ...........................................................................................25

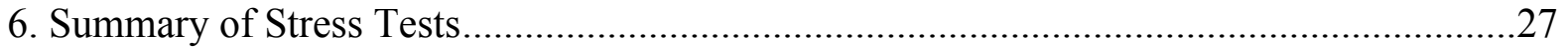

7. Cost of Recapitalization—Default of the Largest Individual Borrower...........................28

Boxes

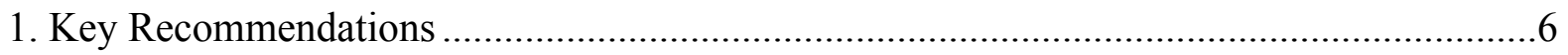

2. Main Conclusions of the CEMAC Regional FSAP …............................................. 14

Appendices

I. Risk Assessment Matrix .............................................................................................22

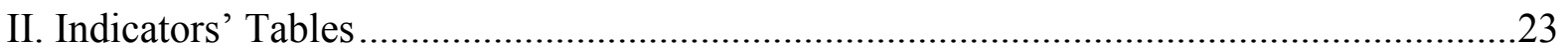

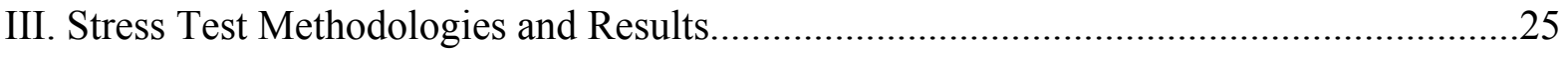




\section{GLOSSARY}

$\begin{array}{ll}\text { AFD } & \text { Agence Française de Développement } \\ \text { APEC } & \text { Professional Association of Credit Establishments } \\ \text { AUPC } & \text { Acte Uniforme sur les procédures collectives d'apurement du passif...... } \\ \text { BEAC } & \text { Bank of Central African States (Banque des États d'Afrique Centrale) } \\ \text { CAR } & \text { Capital adequacy ratio } \\ \text { CEMAC } & \text { Central African Economic and Monetary Community (Communauté } \\ & \text { Economique et Monetaire des États de l'Afrique Centrale) } \\ \text { CEN-SAD } & \text { Community of Sahel-Sahara States } \\ \text { CIMA } & \text { Conférence Interafricaine des Marchés d'Assurance } \\ \text { CNPC } & \text { China National Petroleum Company } \\ \text { CNPS } & \text { National Social Security Fund (Caisse Nationale de Prévoyance Sociale } \\ \text { CNRT } & \text { National Retirement Fund (Caisse Nationale de Retraite du Tchad) } \\ \text { COBAC } & \text { Central Africa Banking Commission (Commission Bancaire de l'Afrique } \\ & \text { Centrale) } \\ \text { DNA } & \text { National Insurance Authority } \\ \text { FOGADAC } & \text { Central Africa Deposit Guarantee Fund (Fonds de garantie des dépôts en } \\ & \text { Afrique Centrale) } \\ \text { FSSA } & \text { Financial System Stability Assessment } \\ \text { MATUH } & \text { Ministry of Urban Development and Housing (Ministère de } \\ \text { l'Aménagement du Territoire, de l'Urbanisme et de l'Habitat) } \\ \text { MFIs } & \text { Microfinance Institutions } \\ \text { NPLs } & \text { Nonperforming Loans } \\ \text { OHADA } & \text { Organization for the harmonization of business law in Africa } \\ \text { Organisation pour l'Harmonisation en Afrique du Droit des Affaires) } \\ \text { RCCM } & \text { Real Estate Registry (Registres de Commerce et de Crédit Mobilier) } \\ \text { SMEs } & \text { Small- and Medium-Sized Enterprises } \\ \text { UMAC } & \text { Union Monétaires de l'Afrique Centrale }\end{array}$




\section{EXECUTIVE SUMMARY}

1. The Chadian financial system has little depth, is segmented, and is exposed to significant risks. The system is among the least developed in the CEMAC region and besides the economy's high dependence on oil revenue, vulnerabilities stem from two main factors. First, direct and indirect bank exposures to the government are massive (around 70 percent of bank portfolios) and many banks do not comply with the single large borrower limit nor the risk concentration ratio set by the regional regulator. Second, four of the eight banks have significant public ownership and suffer major weaknesses, including a negative net worth as a group and interference by the state in management and staffing decisions. Financial stability and growth require a commitment to boost capital buffers, and willingness by the public sector to withdraw from bank ownership and control.

2. The weak legal and judicial environment also weighs heavily on the financial system. Chad scores poorly accordingly to the World Bank Governance Indicators, and is in the lowest decile in the rule of law indicator. Reforms are needed to restore confidence in the judicial system, especially the commercial courts. An effective office of the inspector general of the justice system would constitute a first step in fighting the perception by the business community of pervasive corruption.

3. A further handicap to the banking sector is the weakness in government cash management. The overall economy has rebounded in the last year, but despite high fiscal revenues, the government significantly delays payment of invoices, which has caused a deterioration in the quality of bank loans to government suppliers.

4. Active participation of Chad's treasury in the nascent regional public debt market could help. Regular and preannounced issues of one-, three-, and nine-month treasury bills (t-bills) in the regional public debt market would enable the Treasury to manage its liquidity, reduce payments arrears, and should have positive effects on the CEMAC's banking system.

5. Even though the regional crisis management and resolution framework in the CEMAC is in the process of being strengthened it has not been effective in Chad. The regional banking commission (COBAC) needs to expand its human resources and capacity to be in a position to issue early warnings to prevent crises at the national level. There are delays in implementing decisions on restructuring or resolution of troubled banks, which result in considerable additional costs. Finally, the reform of the regional legal framework for dealing with problem banks needs to be completed.

\section{Strengthening financial intermediation to increase investment and growth}

requires addressing a number of structural weaknesses. In the area of contractual savings, the insurance sector is small compared with peer countries and poorly managed. The National Insurance Authority (DNA) needs to be strengthened to comply better with the legal and prudential framework of the CIMA, ratified in early 2011. The two pension funds, Caisse Nationale de Prévoyance Sociale (CNPS) and the Caisse Nationale de Retraite du Tchad (CNRT), have large claims on the government relative to their asset base. The CNPS has an outdated legal framework and is poorly managed; while the CNRT system lacks 
financial autonomy, is burdened with government arrears, and is insolvent. The government should repay its debt to the two funds and remain current on its future obligations.

7. Access to finance is limited and lending by the banking system is concentrated on a few large enterprises and some SMEs with business relationships with these large corporations. Financial products and services are limited and not adapted to the needs of the SMEs and the absence of long-term resources limits the ability of banks to finance investment needs of SMEs. Moreover, banks do not have access to reliable financial information on potential borrowers. It is important to strengthen the accounting profession and recourse by SMEs to accountants to enhance financial transparency and expand the range of activities that can be financed. The BEAC should develop an adequate credit reporting system and the government should promote the use of the accounting system by businesses.

8. Housing finance is underdeveloped in Chad. Only a narrow segment of large enterprise employees, banks, or senior public officials have access to housing finance despite significant housing needs. The complexity and the cost of the real estate registration system limit the scope of the mortgage market. The government could provide incentives for savings accounts used to build down payments for mortgage loans. The financing offered in rural areas is likewise limited and mainly concentrated on the financing of cotton. Mobile phone payments have the potential to make financial services available to populations in remote areas. The BEAC has prepared draft CEMAC-UMAC regulations on the issue of e-money.

9. Savings-and-loan associations organized into networks constitute the most widespread institutional structures for microfinance in Chad. Farmers are their main target market and represent close to 60 percent of the customer base, followed by stockbreeders and fishermen in a distant second place. The financial viability of MFIs is mixed and only one MFI network out of six is financially viable without external assistance. The government should refrain from further direct intervention in the operations of microfinance institutions. The effectiveness of MFI supervision is weak. The COBAC is responsible for MFI supervision but its resources are inadequate for effective discharge of its responsibilities. 


\section{Box 1. Chad: Key Findings and Recommendations}

\begin{tabular}{|c|c|c|c|c|}
\hline Area & Finding & Recommendations & Priority/Timeframe & Responsibility \\
\hline \multirow[t]{2}{*}{$\begin{array}{l}\text { Banking } \\
\text { sector } \\
\text { stability }\end{array}$} & $\begin{array}{l}\text { Two public banks have } \\
\text { negative equity. }\end{array}$ & $\begin{array}{l}\text { Recapitalize the banks and } \\
\text { prepare a viable business } \\
\text { plan. }\end{array}$ & High/Immediate & Government \\
\hline & $\begin{array}{l}\text { The banks do not } \\
\text { comply with the limits } \\
\text { on individual exposure, } \\
\text { despite the very } \\
\text { generous threshold. }\end{array}$ & $\begin{array}{l}\text { Increase capital to enhance } \\
\text { resilience to shocks. }\end{array}$ & High/by 2014 & CEMAC \\
\hline $\begin{array}{l}\text { Cash flow and } \\
\text { public debt } \\
\text { management }\end{array}$ & $\begin{array}{l}\text { Poor government cash } \\
\text { flow management leads } \\
\text { to financial } \\
\text { vulnerabilities. }\end{array}$ & $\begin{array}{l}\text { Establish, under the } \\
\text { leadership of the Ministry } \\
\text { of Finance, with the active } \\
\text { participation of the BEAC, } \\
\text { and line ministries, a } \\
\text { treasury committee to } \\
\text { monitor the government's } \\
\text { cash position. }\end{array}$ & High/Immediate & $\begin{array}{l}\text { Government } \\
\text { BEAC }\end{array}$ \\
\hline $\begin{array}{l}\text { Access to } \\
\text { financial } \\
\text { services }\end{array}$ & $\begin{array}{l}\text { Access to services is } \\
\text { constrained by the lack } \\
\text { of adequate information } \\
\text { on borrowers. }\end{array}$ & $\begin{array}{l}\text { The BEAC should develop } \\
\text { an adequate credit } \\
\text { reporting system and the } \\
\text { government encourages the } \\
\text { use of the accounting } \\
\text { system by businesses. }\end{array}$ & High/Medium term & $\begin{array}{c}\text { BEAC/ } \\
\text { Government }\end{array}$ \\
\hline Microfinance & $\begin{array}{l}\text { The government plays } \\
\text { the role of a direct } \\
\text { operator in the sector by } \\
\text { extending credit. }\end{array}$ & $\begin{array}{l}\text { Limit direct intervention } \\
\text { by the government in the } \\
\text { sector in support of } \\
\text { existing institutions based } \\
\text { on a performance contract. }\end{array}$ & $\begin{array}{l}\text { Medium/Medium } \\
\text { term }\end{array}$ & Government \\
\hline \multirow[t]{2}{*}{$\begin{array}{l}\text { Housing } \\
\text { financing }\end{array}$} & $\begin{array}{l}\text { No long-term resources } \\
\text { are available. }\end{array}$ & $\begin{array}{l}\text { Develop incentives for } \\
\text { savings accounts for the } \\
\text { constitution of down } \\
\text { payments for mortgage } \\
\text { loans, including explicit } \\
\text { budgeting of direct } \\
\text { assistance to borrowers. }\end{array}$ & $\begin{array}{l}\text { Medium/Medium } \\
\text { term }\end{array}$ & Government \\
\hline & $\begin{array}{l}\text { Demand for housing } \\
\text { finance is unmet } \\
\text { because security of } \\
\text { operations is weak. }\end{array}$ & $\begin{array}{l}\text { Take measures to enforce } \\
\text { the new OHADA law, } \\
\text { which makes it possible to } \\
\text { mortgage future real } \\
\text { property. }\end{array}$ & Medium/Immediate & Government \\
\hline \multirow[t]{2}{*}{$\begin{array}{l}\text { Legal and } \\
\text { judicial } \\
\text { framework }\end{array}$} & $\begin{array}{l}\text { Legal registration of } \\
\text { guarantees and } \\
\text { companies is unreliable. }\end{array}$ & $\begin{array}{l}\text { Modernize the OHADA } \\
\text { RCCM with the support of } \\
\text { the Committee experts and } \\
\text { on basis of the Guide } \\
\text { produced by OHADA. }\end{array}$ & $\begin{array}{l}\text { Medium/Medium } \\
\text { Term }\end{array}$ & \\
\hline & $\begin{array}{l}\text { The business } \\
\text { community has no }\end{array}$ & $\begin{array}{l}\text { Establish a credible } \\
\text { inspector general's office }\end{array}$ & High/Near Term & \\
\hline
\end{tabular}




\begin{tabular}{|c|c|c|c|c|}
\hline Area & Finding & Recommendations & Priority/Timeframe & Responsibility \\
\hline & $\begin{array}{l}\text { confidence in the } \\
\text { judicial system. }\end{array}$ & $\begin{array}{l}\text { to investigate and } \\
\text { prosecute corruption in the } \\
\text { justice system and } \\
\text { introduce arbitration and } \\
\text { mediation for dispute } \\
\text { settlement outside courts. }\end{array}$ & & \\
\hline $\begin{array}{l}\text { Insurance } \\
\text { sector }\end{array}$ & $\begin{array}{l}\text { The sector is subject to } \\
\text { national supervision, } \\
\text { which does not comply } \\
\text { with CIMA's } \\
\text { regulatory requirements } \\
\text { as applied in the other } \\
\text { countries of the region. }\end{array}$ & $\begin{array}{l}\text { Reform the National } \\
\text { Insurance Directorate } \\
\text { (DNA), by providing it } \\
\text { with its own board, staff, } \\
\text { and independent budget } \\
\text { funded through direct } \\
\text { allocations to the DNA of } \\
\text { supervision levies paid by } \\
\text { companies. }\end{array}$ & Medium/Near Term & $\begin{array}{l}\text { Ministry of } \\
\text { Finance }\end{array}$ \\
\hline $\begin{array}{l}\text { Pension } \\
\text { sector }\end{array}$ & $\begin{array}{l}\text { The CNRT has been } \\
\text { technically bankrupt for } \\
20 \text { years. } \\
\text { The CNPS has an } \\
\text { overall surplus that } \\
\text { could be used to } \\
\text { preserve the purchasing } \\
\text { power of pensioners } \\
\text { and maintain the } \\
\text { financial viability of the } \\
\text { pension system. }\end{array}$ & $\begin{array}{l}\text { The government should } \\
\text { repay its debts to the two } \\
\text { funds and remain current } \\
\text { on its future obligations. } \\
\text { Conduct an actuarial study } \\
\text { to help establish the long } \\
\text { term financial viability of } \\
\text { the system. }\end{array}$ & High/Immediate & $\begin{array}{l}\text { Ministry of } \\
\text { Finance/ } \\
\text { Ministry of } \\
\text { Labor }\end{array}$ \\
\hline
\end{tabular}




\section{MACROECONOMIC ENVIRONMENT}

\section{A. Macro-Financial Context and Risks}

11. Chad is a low-income country, highly dependent on oil and agriculture. Oil exports began in 2003 but only totaled about 45 million barrels in 2010, about 1 percent of total Sub-Saharan African production; this still represents 62 percent of Chad's nominal GDP and 90 percent of its exports. Remaining proven reserves are modest and are expected to be mostly depleted over the next 20 years. However, recent high oil prices have resulted in a windfall of export earnings and government oil revenue. After oil, agriculture (cotton, cattle, and grains) is the most important source of Chad's export earnings, and provides employment or subsistence for the bulk of the predominantly rural population.

12. Chad is a member of the CEMAC monetary union, with a fixed peg against the euro, and financial sector regulation is also conducted at the regional level. The regional banking commission (COBAC) is responsible for setting bank regulation, for setting prudential norms, for crisis management, and for conducting banking supervision.

13. Growth suffered owing to the negative oil-price shock in 2009, but rebounded in 2010. Real GDP growth reached 13 percent in 2010, on the back of higher oil production in response to high oil prices that spurred additional investment to bolster extraction. Most importantly, with favorable rains and government measures to provide agricultural inputs, as well as an increased cultivation area, agricultural production nearly doubled and food and consumer prices declined. Strong project-related imports kept the current account deficit high, but this was financed in part by continued foreign direct investment in the oil sector.

14. The outlook for 2011-12 is positive, but the balance of payments and public finances remain sensitive to oil price changes. Overall real GDP growth is projected to moderate to 3 percent in 2011. Oil production is expected to decline slightly, despite the contribution from the new, but relatively small CNPC-operated field (Bongor). In June, Bongor began producing 20,000 barrels per day (bpd) to feed the new refinery, which opened shortly thereafter. Non-oil GDP growth is expected to moderate to 3.6 percent in 2011, on account of declining oil and agricultural output. In 2012, growth is expected to spike above 7 percent, reflecting the oil refinery's first full year in operation and new industrial projects entering production, including a power station and a cement factory. Crude oil production is also expected to spike in 2012, although output from the main oil field at Doba is expected to decline or, at best, it could stay at the current level of about 120,000 bpd, provided the international oil prices remain close.

15. Chad's major source of macro risk is oil related. In view of the expected steady decline of oil production, Chad's current fiscal stance raises sustainability concerns. The nonoil primary deficit increased from 3 percent of non-oil GDP in 2003, the first year of oil production, to 30 percent in 2009-10. With non-oil revenue effort of about 12 percent, one fourth less than the average of other Sub-Saharan African oil exporters, there is little to lean 
on once oil production ends. In the short term, Chad's pro-cyclical fiscal policy has made it very vulnerable to oil price shocks. This was particularly pronounced in the context of the 2009 slump in the oil market, leading to a sharp deterioration in both the fiscal and the external positions, a depletion of savings and an increase in domestic public debt. It is important, both to protect the treasury against volatility and to prepare for the eventual end of production, that the authorities rebuild a buffer of oil savings.

16. Chad's banking sector is concomitantly exposed to the government's oilrelated risks. The government, directly or indirectly, is essentially the only significant banking client in Chad. It is the banks' single largest exposure, and the remaining exposure is mostly to public enterprises that export agricultural products, government suppliers or contract holders, or public servants. Banks are therefore vulnerable to the macroeconomic shocks associated with fluctuations in the prices of export products - oil and cotton, in particular, and they have a high credit risk as a result of the concentration of their portfolio on a very limited number of clients. The accumulation of payments arrears by the government treasury has resulted in an increase in the risk of default by the governmentrelated bank clients.

17. Bank liquidity has improved somewhat, partly stemming from oil company deposits made to cover local currency spending. This has enabled the sector to provide funding to the government, largely indirectly in the form of notes payable by public enterprises, without crowding out the private sector. Broad money expanded by 26 percent in 2010 compared to the 17 percent growth rate of nominal GDP, with only slightly slower growth in credit to the private sector.

\section{B. Public Debt Management}

18. Poor treasury cash management contributes to financial vulnerabilities. Chad has had to extend the offering period of its bonds to investors, despite the high interest rate and modest levels of government indebtedness, owing to perception of a weakening fiscal position caused by pervasive delays in payments to government domestic suppliers.

Moreover, the implementation of an ambitious investment program to build infrastructure has led to extended payment delays to government suppliers despite the oil windfall. The delays are an increasing source of delinquencies on small business debt to banks, thus contributing to an increase in nonperforming loans (NPLs).

\section{The treasury needs to fully participate in a modern payments system and} become an active player in the regional government securities market. The regional monetary authorities have decided to phase out the BEAC's overdraft facility to national treasuries and to clear existing outstanding debt resulting from its use. Chad's treasury needs to rapidly modernize its operations and take an active role in the regional money market by issuing short-term treasury bills and gradually building a full yield curve by extending 
maturities, at least up to five years. ${ }^{1}$ This would improve cash management and reduce significantly payment delays.

\section{Structure OF The FinAnCial SeCtor AND VuLnerabilities}

\section{The financial system has a narrow base, little depth, and is under-developed}

(Table 1). There are eight commercial banks, two insurance companies, two pension funds, and over 200 microfinance institutions (MFIs). The banking system is one of the least developed in the CEMAC region: total assets are only about 12 percent of GDP, below the 19 percent average for the CEMAC. With less than one branch per $1000 \mathrm{~km} 2$, Chad has the least dense banking network in CEMAC. (There are also only 13 bank accounts per 1,000 inhabitants compared with 52 in Cameroon). Commercial banks, which dominate the financial sector, offer a narrow range of financial products: as of end-2010, short-term loans accounted for about 55 percent of total assets, compared to 44 percent for medium-term loans, and less than 2 percent for long-term loans; on the liability side, time deposits dominate, followed by the demand deposits and passbook savings account. The conditions for opening bank accounts are often prohibitive for the poorest segments of the population (some banks require a minimum of CFAF $200,000^{2}$ to open a bank account). Two competing stock exchanges have been created in the zone, ${ }^{3}$ but no Chadian companies are registered.

Table 1. Chad: Structure of Financial System 2010

\begin{tabular}{l|c|r|r|r}
\hline & \multirow{2}{*}{$\begin{array}{l}\text { Number of } \\
\text { institutions }\end{array}$} & \multicolumn{3}{|c}{ Assets } \\
\cline { 3 - 5 } & & $\begin{array}{c}\text { in billions } \\
\text { of CFAF }\end{array}$ & $\begin{array}{c}\text { Percent of } \\
\text { Assets }\end{array}$ & $\begin{array}{c}\text { Percent of } \\
\text { GDP }\end{array}$ \\
\hline Banks & 8 & 498 & 81.5 & 11.8 \\
Insurance companies & 2 & 14 & 2.3 & 0.3 \\
Pension funds & 2 & 90 & 14.7 & 2.1 \\
Microfinance institutions & 202 & 9 & 1.4 & 0.2 \\
Total & & 611 & 100 & 14.4 \\
\hline
\end{tabular}

Source: COBAC.

\footnotetext{
${ }^{1}$ The regional central bank, the BEAC, has recently established a framework for a regional government debt market. Three countries in the region have issued treasury bonds, which were syndicated and are costly in terms of fees and interest rates. The BEAC is now ready to assist, free of fees, member countries with auctions of treasury bills in the market.

${ }^{2}$ Equivalent to the monthly salary of a senior civil servant.

${ }^{3}$ One in Cameroon (the Douala Stock Exchange, DSX), launched in 2005, and the other in Gabon (La Bourse des Valeurs Mobilières de l'Afrique Centrale, BVMAC), which began to operate in 2006.
} 
22. The financial system comprises mostly foreign-owned banks. The capital of all Chadian banks is largely held by foreign investors: 65 percent of bank assets are held by foreign banks-including the French Société Générale, the Nigerian UBA, and the West African ECOBANK Group-while the remaining 35 percent are held by the governmentcontrolled banks. Two pension funds and two insurance companies compose the remainder of the financial system. A multitude of MFIs, mainly based in rural areas, provide limited financial services to the population in poor areas.

\section{A. Soundness and Performance}

23. The financial soundness of the Chadian banking system has been deteriorating for several years. Two state banks are being restructured and the quality of their assets continues to deteriorate. Prudential limits to large exposures are rarely respected despite the high limits set by COBAC. The minimum capital was raised to CFAF 5 billion at end June 2010, but two state banks, including one under restructuring, have negative equity. ${ }^{4}$ Asset quality has declined: the ratio of NPLs increased from 10.4 percent in 2009 to 12.1 percent in 2010. The rate of provisioning of NPLs improved in 2010 but remains at only 73.5 percent. Despite the high level of NPLs, the profitability of the banking system appears adequate since banks apply high gross margins on loans. ${ }^{5}$ The reported capital is overstated by NPLs, and the adjusted capital reflects the correction for under-reporting and underprovisioning NPLs (Table 2).

\section{Bank resources come mainly from short-term deposits and transformation is} very limited, reflecting a lack of collateral and the weak legal framework. Close to 80 percent of all bank deposits are on demand or at terms of less than one year. Similarly, about 70 percent of loans are short-term.

25. The greatest vulnerabilities of the banking sector stem from its exposure to the public sector and to a few large private companies. The government and public entities hold, respectively, roughly a third of banking system deposits, and as much as three fourths of deposits in some banks. Bank loans generally fund expenditure by government and large companies in the cotton, sugar, and oil sectors. Outside these sectors, there are very few creditworthy borrowers who can provide banks with satisfactory documentation to assess risk for loan decisions. The data at end-March 2011 show that almost half of all loans go to fewer than 30 companies; the largest state company alone accounts for almost 8 percent of gross lending. The government maintains its monopoly of cotton, water, fixed-line telephony, postal services, and electricity. Large private sector companies are also closely associated with the public sector through service contracts with the government. The government-

\footnotetext{
${ }^{4}$ The minimum capital requirement should be raised further to CFAF 10 billion by June 2014 .

${ }^{5}$ The significant increase in the return on assets (ROA) and return on equity (ROE) between 2009 and 2010 mainly reflects the negative equity of two banks and exceptional profits by a large bank following the assumption by the government of NPLs which had been provisioned.
} 
suppliers-employees chain has amplified the interconnectedness of the bank and nonbank sectors and increased the banks' exposure to macroeconomic risk. About 70 percent of gross loans were extended to the public sector and related activities in Chad.

Table 2. Chad: State-Owned Banks Vs. Foreign Private Banks Soundness Indicators

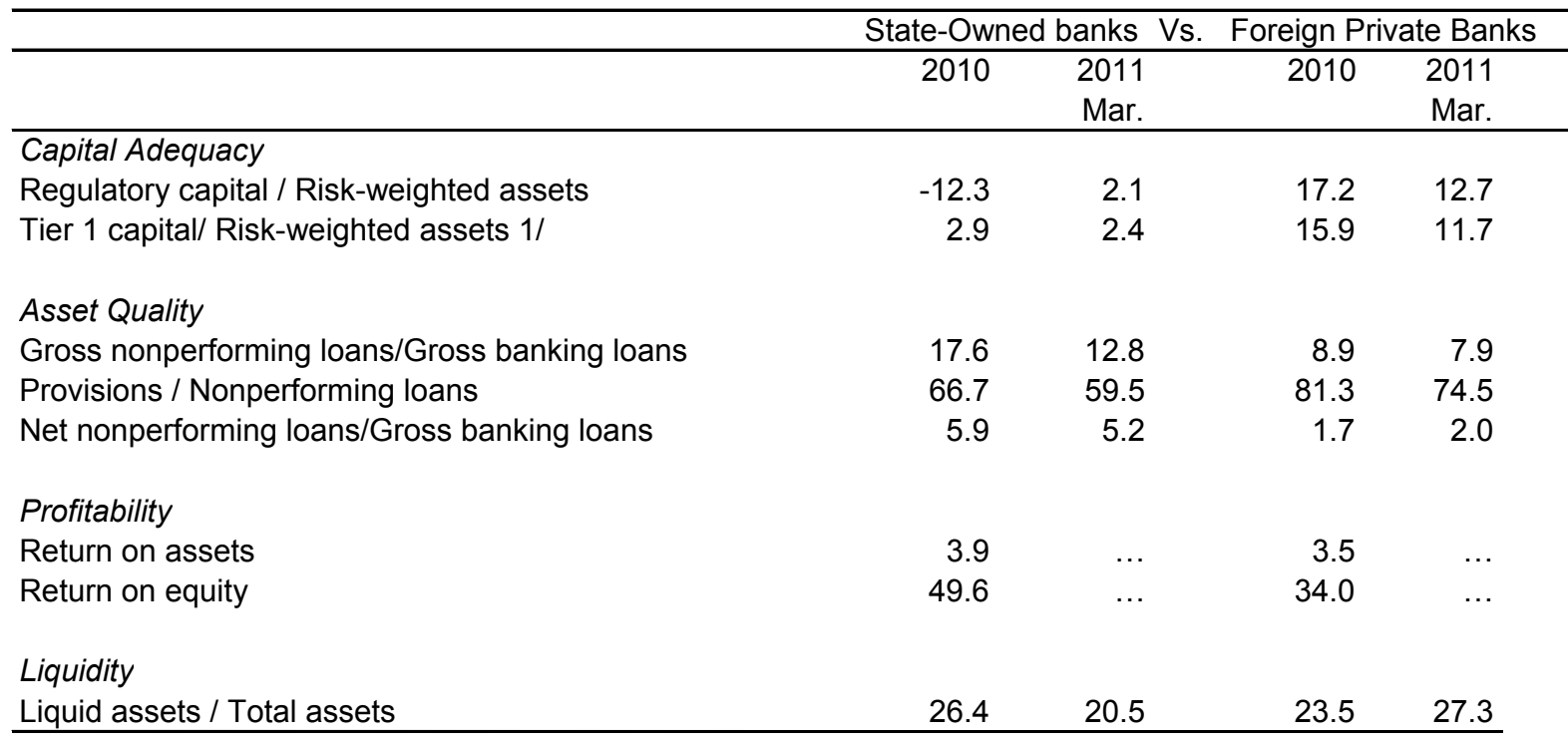

Source: COBAC.

1/ Data reflect 8 banks in Chad. Due to the supervisory charges on some banks, tier 1 capital is larger than regulatory capital for 2009.

26. The impact of the Libyan crisis is a matter of concern. Libya holds a 50 percent share in one bank, while another bank is controlled by a bank owned by the thirteen member states of the CEN-SAD (the group of Sahel-Sahara States led by Libya) and headquartered in Tripoli, Libya. These banks have temporarily suffered massive withdrawals due partly to the Libyan crisis. Even though the pressure on deposits seemed to have abated at the time of the mission, the liquidity situation remains fragile and, if recapitalization were needed, shareholders would be hard pressed to mobilize the required financing. The banks with Libyan interests as well as other state banks need recapitalizing and the Chad government should use this opportunity to attract private investors or close the banks that do not have a credible business plan proving their financial viability. Thus, it would help minimize government involvement in the banking sector.

\section{B. Short-Term Vulnerabilities}

\section{Reported data suggest that all banks are vulnerable to credit risk, although} foreign-owned banks would be more resilient to most shocks (Appendix III). Two state banks have negative capital (after adjustment). The larger of these two banks and a third state bank were under restructuring and were excluded from the stress tests. All foreign-owned banks complied with the required increase in the minimum capital and (based on March 2011 data) have a weighted capital adequacy ratio (CAR) of 12.6 percent. State-owned banks had an aggregate CAR of -0.6 percent compared to a required minimum of 8 percent. System 
NPLs, excluding a public bank, whose NPLs were equivalent to 63.5 percent, were estimated at 10.2 percent of gross loans. Stress tests show that, while foreign-owned private banks would remain adequately capitalized even with a 50 percent increase in NPLs, the government-controlled banks examined would need substantial recapitalization, and the overall banking system CAR would fall to around 8 percent.

28. Banks' portfolios are highly concentrated and all banks breach the single large exposure limit. While the COBAC has set the limit at 45 percent of capital, actual exposure exceeds 100 percent of capital. Stress tests show that if the largest public borrower were to default only one foreign owned bank would meet the regulatory capital adequacy ratio, while all state banks would have negative capital and two other foreign owned banks would need additional capital. The default of the largest private borrower would also reduce the CAR for state banks to a negative 4 percent, but all foreign owned banks would meet the regulatory CAR.

\section{Supervision and Crisis Management}

29. As noted in the 2006 CEMAC FSAP (Box 2), the effectiveness of the regional supervisor (COBAC) is severely compromised by inadequate resources. The Chad FSAP mission did not conduct a BCP assessment because supervision is conducted at the regional level by the regulatory and supervisory authority, but substantial supervisory shortcomings were found in the regional assessment. In Chad, the COBAC aims at conducting onsite supervision for each bank every other year. However, due to resource limitations, it may take up to four years for a bank to be subject to a comprehensive or even a thematic inspection. Furthermore, it may take the COBAC a long time before it detects deterioration in the soundness of a bank because of poor offsite supervision, which mainly focuses on detecting data inconsistencies. Finally, monthly bank credit reports detailing their lending operations and individual payments delays or delinquencies, which are provided to the BEAC national branch, are communicated to the COBAC after they are processed; COBAC should have access to the raw data.

30. The effectiveness of COBAC's actions also suffers from an inadequate regional legal framework for dealing with banking crises. It is expected that a new region-wide regulation on the resolution of banking crises to be adopted by year-end will strengthen the powers of the COBAC. In particular, this regulation, which benefited from the IMF's technical assistance, is expected to allow the authorities to take early intervention measures to resolve banking crises, to define clearly the responsibilities of regional and national bodies and the scope of judicial review, and to prevent questionable shareholders from participating in a bank restructuring.

31. The regional deposit guarantee fund, (Fonds de Garantie des Dépots en Afrique Centrale-FOGADAC) was formally established in 2009 and accepted its first contributions in March 2011. The mission of this fund, which is administered and managed by the BEAC/COBAC in conjunction with the Professional Association of Credit Establishments (APEC), is to reimburse small- and medium-sized depositors (deposits are insured up to CFAF 5 million per customer) in the event that a bank fails. The fund can also engage in preventive intervention by granting loans, when it appears that such steps would 
safeguard a bank's solvency and save the fund from having to repay depositors. All FOGADAC resources can be used to guarantee the deposits in any of the banks established in the CEMAC, but there is no consolidated approach to a possible crisis affecting several entities in a group operating in several CEMAC countries.

\section{Box 2. Main Conclusions of the CEMAC Regional FSAP}

The findings of the CEMAC regional FSAP (SM/06/210) were discussed by the Executive Board in the context of the 2006 CEMAC Article IV Consultation. The main conclusions are:

- $\quad$ Regional integration of the banking sector, which dominates the financial system, is held back by limited intra-regional trade and market infrastructure deficiencies.

- $\quad$ The banking system is vulnerable to concentration of lending to a few borrowers; the cost of recapitalization under the worst-case scenario would be limited.

- $\quad$ The efficiency of the supervisory framework suffers from limited independence of the supervisory authority (the COBAC), the need to better align prudential norms with best practices, and inadequate resources allocated to the COBAC.

- Financial intermediation is amongst the lowest in Africa. Competition is limited due to rigid and out of line with market fundamentals interest rates; the severe deficiencies in the legal and judicial framework; poor quality of financial data; and weak payments systems.

Insufficient centralization of government deposits at the BEAC and weaknesses in the monetary policy framework limit BEAC's ability to conduct effective monetary operations to manage excess liquidity, and thus exacerbate financial system vulnerabilities.

32. More active involvement of the BEAC national branch in ongoing supervision is would be highly desirable. But to be effective, a number of actions are required including: (i) reestablishment of the role of COBAC local correspondent, providing the necessary human resources for the task; (ii) systematic use of the data collected in all areas related to banking activity; (iii) establishment of a periodic survey, on at least a quarterly basis, submitted to the COBAC General Secretariat; (iv) definition of early warning indicators, which should be quickly reported to the COBAC General Secretariat; (v) participation of the "local COBAC correspondent" in onsite inspections conducted by COBAC; and (vi) determination of the operational responsibilities to be entrusted to the BEAC national branch when a bank is made subject to close supervision.

\section{Strengthening FinAnCIAL SECTOR INTERMEDIATION}

\section{A. Contractual Savings}

\section{Insurance sector}

33. The Chadian insurance sector is small compared with peer countries, and poorly managed. The total assets of the sector amounted to only CFAF 14 billion in 2010 and turnover was about CFAF 9 billion, with a penetration (premiums/GDP) of 0.27 percent (as opposed to a median of 0.89 percent in the CIMA zone) and a density (premiums/inhabitants) 
of CFAF 837 (as opposed to a median of CFAF 2,112 in the CIMA zone). The main insurance company has market share of about 70 percent and the second operator, licensed in 2002, has the remaining. Management fees and commissions are extremely high, absorbing about 28 percent and 8 percent, respectively, of premiums, and about half of net reinsurance premiums.

34. The CIMA prudential framework needs to be implemented. The National Insurance Authority (DNA) needs to be strengthened to comply better with CIMA regulations. This would require: (i) setting up its own board, staff, and an independent budget (funded by fees paid by companies); (ii) reorganizing and improving the quality of audit activities and enforcing sanctions; and (iii) enforcing the legal and prudential framework of the CIMA, ratified in early 2011, in particular with regard to the monitoring of brokers.

\section{Pensions}

35. The two pension funds in Chad have large claims on the government relative to their asset base. The Caisse Nationale de Prévoyance Sociale (CNPS) is the pension system for private sector employees and for government employees not covered under the civil service system. Its assets are estimated at about CFAF 50 billion, and its claims on central government and other public sector institutions at about 25 percent of its total assets. The second pension fund, the Caisse Nationale de Retraite du Tchad (CNRT), is the pension fund for civil servants and the military. Its assets are estimated at about CFAF 40 billion and its claims on the central government represent more than 90 percent of total assets. Government debt to pension funds arose mostly from the treasury's failure to pay in the funds due by the government and its employees.

36. The CNPS has an outdated legal framework and is poorly managed. The legal framework dates back to the 1970 s, and is ill suited to meet the requirements of an adequate social welfare regime. It operates under tight control of the department of labor, and its management has had no autonomy in decision-making. Moreover, the legal framework needs to be adapted to reflect changes in the labor market, allowing the introduction of a voluntary insurance scheme to extend coverage to the assets of nonmembers (or a mandatory scheme for some independent entities), the introduction of supplementary pension schemes, and the possible establishment of a full-fledged national health insurance system. CNPS' investment portfolio is worth about CFAF 25 billion distributed as follows: CFAF 5 billion in rental property, but some of this property has been seized, without compensation, by government, CFAF 0.8 billion in equity, and CFAF 5.4 billion in time deposits and CDs.

CFAF 14.3 billion are deposited in non-interest-bearing current accounts, well above benefits to be paid in the short term.

37. The CNRT system lacks financial autonomy, is insolvent, and is burdened with government arrears. Although technically bankrupt since its establishment in 1993, the CNRT had more than CFAF 25 billion in arrears on pension payments in 2009. The financial viability of the CNRT would require a restructuring plan including: (i) the clearance of government debt; (ii) the payment of arrears to pensioners; (iii) an actuarial study of new income and expenditure, with the overall financing plan for the regime and the rehabilitation 
of its balance sheet; and (iv) an institutional reform that would give it operational and managerial autonomy.

\section{B. Access to Finance}

Financing small-and medium-sized enterprises (SME)

38. As noted above, lending by the banking system is concentrated on a few large enterprises and some SMEs with business relationships with these large corporations. At end 2010, 60 percent of credit to the economy was concentrated on large enterprises, against 22 percent to SMEs. While banks compete to lend to the few large enterprises, they also seek lending to private individuals, in particular civil servants. Average interest rates on loans to large enterprises and to SMEs were 11.85 percent and 12.19 percent, respectively, compared with a rate of 16.03 percent for individuals, in 2010. The small interest rate premium paid by SMEs relative to large enterprises reflects the fact that lending goes to SMEs, which are subcontracts with large enterprises, with risks related to the signatures of latter. The SMEs that have access to credit are subcontractors to large enterprises and hence, have similar risks.

39. Financial products and services are limited and not adapted to the needs of the SMEs. A factor that makes SME financing more difficult is the absence of financial institutions offering specialized products such as leasing, guarantee funds, or factoring products adapted to the structure of the Chadian private sector. In addition, the absence of long-term resources limits the ability of banks to finance investments needs of SMEs.

40. Furthermore, banks do not have access to reliable financial information on potential borrowers. The BEAC has a credit risk bureau (Centrale des Risques-CR), but its effectiveness is hampered by the considerable delay in updating the information collected from the banks. The project to establish a balance sheet center (Centrale des Bilans) and a payment delinquency center (Centrale des Incidents de Paiement) is experiencing setbacks. Furthermore, SMEs seldom seek the assistance of professionals in preparing financial statements and business plans, and a large number of them do not file their financial statements with the courts, as required by law. It is important to strengthen the accounting profession and recourse by SMEs use of accountants so as to enhance financial transparency and expand the range of activities that can be financed by the banks, thereby helping boost growth.

\section{Housing finance}

\section{Housing finance is underdeveloped amounting to only CFAF 23 billion or} 0.7 percent of GDP at end-2010. ${ }^{6}$ Only four of eight banks offer such loans and two of them hold 75 percent of such loans. The majority of loans are medium-term, often without a mortgage guarantee or with flawed guarantees, such as promised mortgages on unregistered

\footnotetext{
${ }^{6}$ However, the ratio of housing loans to the total loan balance is not negligible (7.8 percent), which reflects the limited penetration of the banking system in general and the importance of cash circuits.
} 
property. The loans are extended at high fixed rates, which are adjustable under the contracts based on the cost of lender resources, although some competition seems to be emerging because the range of terms offered (12-17 percent) is trending downwards. ${ }^{7}$ Only a slim segment of large enterprise employees, banks, or senior public officials have access to this financial service. Yet housing needs are significant and growing, in particular as a result of rapid urban sprawl. ${ }^{8}$

\section{The complexity and the cost of securing property rights constrain the}

development of the mortgage market. The procedures for securing land tenure and the issuance of titles, which involve multiple government agencies, with ill-defined responsibilities, are time-consuming and confusing. Transaction costs are high and include registration fees of 10 and 15 percent of the value of developed and undeveloped property, respectively. As a result, less than 20 percent of properties are properly registered, ${ }^{9}$ many buildings are constructed without permits, provisional and questionable titles abound. Understating sale prices and property improvement is therefore common practice, and many legal requirements are not met. Administrative property valuations are used as references for market transactions rather than for tax purposes, thereby distorting prices.

\section{Rural financing}

43. The financing offered in rural areas is very limited, as the bank whose initial mandate was to finance agriculture has experienced a number of problems. Its only intervention in rural financing consists of participating in the financing of cotton. Therefore, MFIs provide the bulk of lending to farmers. Several financial products have been developed to meet the needs of the rural and agricultural sector, such as warrants (warrantage). The very limited technical capacity of the MFIs and their lack of financial resources are major drawbacks to the development of their support for the rural sector (see section below).

44. The financial services of the postal system, with its 36 offices throughout the country, could be a channel for distributing financial services in remote areas. Postal financial services were suspended several years ago after a number of problems. Postal checking services have been resumed but savings products are still not offered. Several avenues are open to the postal service: (i) develop a full-fledged financial institution, separate from the postal services with its own products; (ii) agree to a hosting understanding with a bank or an MFI; (iii) agree with a mobile payments supplier to provide hosting services.

45. Mobile phone payments have the potential to make financial services available to populations in remote areas. Stimulated by the growth of mobile phone payment systems in other sub-Saharan countries, several banks in Chad are having discussions with telephone

\footnotetext{
${ }^{7}$ Housing loans are VAT exempt.

${ }^{8}$ The housing deficit was evaluated at 125,000 units back in 1999 and new needs are estimated at 25,000 units per year.

${ }^{9}$ There are fewer than 4,000 property titles in the entire country, including government properties.
} 
companies to introduce mobile telephone payment arrangements in the country. The BEAC has prepared draft CEMAC-UMAC regulations on the issue of e-money.

\section{Microfinance}

46. Savings-and-loan associations organized into networks constitute the most widespread institutional structures for microfinance in Chad. As of December 31, 2010, the sector had six networks covering almost 95 percent of the active MFIs. With the exception of one, all networks operate in rural areas. The vast majority of these independent MFIs (nine out of 13) operate in rural areas even though the two largest operate only in N'Djamena.

47. Farmers are the main target market and represent close to 60 percent of the customer base, followed by stockbreeders and fishermen in a distant second place. The resources consist mainly of unremunerated demand deposits or time deposits remunerated at an average annual interest rate of 4-6 percent. The loans, tailored to the needs of farmers, are generally crop credits, with maturities of one year or less, and monthly interest rates of about 2 percent, which are reimbursed after the harvest. Investment credits are typically for more than one year and applicable monthly interest rates are in the range of 1.5 percent. Other products for the rural area, such as warrants, were introduced by certain MFIs, but difficulties related to storage capacity and high transportation costs have slowed their growth.

48. The financial viability of MFIs is mixed. Only one MFI network out of six is financially viable without external assistance. The others rely heavily on donor subsidies to operate: these in some cases account for up to 70 percent of the operating budget of the beneficiary MFI. However, the overall profitability of the sector is based mainly on the performance of two of the three largest networks, which account for 73 percent of the total balance sheet of the sector and benefit from subsidies from donors.

49. The effectiveness of MFI supervision is weak. The COBAC is responsible for MFI supervision but it lacks resources to discharge its responsibilities effectively, even with regard to the MFIs grouped into networks, and the prudential framework for MFIs needs to be updated. The COBAC should assess the enforcement of the supervisory framework for microfinance and enhance the effectiveness of its current supervisory responsibility, including through strengthened use of its reporting system and cooperation with the financial institutions responsible for MFI networks.

\section{Regional Financial Integration}

50. There has been progress with regional integration in recent years, but the results are mixed. The first sign of regional integration in the CEMAC is the freedom of movement of capital throughout the zone and the application of the same interest rates by the BEAC across the region. In general, financial flows follow trade flows. Measured by the number of BEAC banknotes that are exported, Chad's integration into the CEMAC is tenuous and essentially limited to Cameroon and the Central African Republic, its major economic partners. According to the most recent data, 60 percent of the CFAF banknotes entering Chad came from Cameroon and 24 percent from the Central African Republic. 
51. The government of Chad has just launched its first treasury bonds issue on the financial markets. The securities can be purchased on the two stock exchanges of the CEMAC, the Douala Stock Market and the Libreville Regional Stock Market. Chad is not represented on either of the two stock exchanges. Brokerage agencies would raise the awareness of the population and enterprises of the services offered by the regional financial markets, help mobilize long-term saving, make long-term financing available to Chad, and facilitate regional integration. The launching of a bond loan in all the CEMAC countries would be a sign of the integration of the Chadian market and its attractiveness to regional investors.

\section{There has been an increase in bank loan syndication in the CEMAC in recent} years. The Chadian banks participated in bank syndicates and CEMAC banks participated in bank syndicates in Chad. COBAC's prudential rules encourage bank syndicates to facilitate risk diversification. The Chadian banks are also small, which makes it impossible for them to single-handedly meet financing demands that are large relative to their equity base.

\section{The single license introduced in the CEMAC to promote regional integration}

has not been effective. It was designed to make it easier for a bank that is licensed in one CEMAC country to operate in the others. To date, no bank has used this facility. The concept of a single license seems inadequate. Banks must meet minimum capital requirements for each subsidiary and their managing directors must be authorized by the COBAC. It would have been preferable to allow banks to operate by branch/agency, as they do within a single country, without the minimum capital or managing director requirements. The COBAC would then exercise general supervision of the bank at the CEMAC level and the bank would have sufficient capital to sustain its operations in all the countries of the area where it is established.

\section{Legal and Judicial Environment for Lending}

54. The quality of the legal and judicial environment plays an important role in access to financial services. In Chad, financial activities are subject to regulations enacted at different levels, including by OHADA, the CEMAC, and in national legislation. For example, the regulatory and supervisory framework for banking and microfinance is enacted by the CEMAC, while that of capital markets is enacted by the CEMAC regional securities market (Commission de Surveillance du Marché Financier de l'Afrique CentraleCOSUMAF), and contract laws, including those governing foreclosures and bankruptcy are under OHADA guidelines. Property law, real estate legislation and judicial procedures are established at the national level. In Chad, There is a strong perception of limited impartiality, effectiveness, and expeditiousness in the functioning of the commercial justice system. Even specialized courts, which comprise one professional judge and one commercial court judge, are reported to be unable to hold regular hearings and rule effectively, thus causing serious delays in the treatment of commercial disputes. For example, during the first half of 2011, there were only four hearings in the N'Djamena commercial court.

55. There is a need for the government to restore confidence in the judicial system. This could be achieved by encouraging impartiality, independence, and effectiveness in the justice system through the reform of the judicial apparatus, including the commercial courts. 
The review of the Code of Civil Procedure and the Penal Code to enhance their effectiveness would be very helpful in that respect. Moreover, the adoption of a code of ethics for magistrates, commercial court judges, and court clerks could contribute to facilitating the handling of disputes and the execution of court decisions within a reasonable timeframe and in an equitable manner. A training program should also be developed for the judges with jurisdiction over commercial matters in particular for the tradesmen who judge their peers (juges consulaires). Furthermore, the lack of legal knowledge on the latter is a considerable obstacle in the treatment of commercial disputes. Arbitration and mediation should be strongly encouraged as an alternative means of dispute settlement.

56. Domestic players do not know the OHADA business law, which hampers its effectiveness in helping the growth of financial services. The government, in close cooperation with market players could usefully organize seminars and other activities to raise awareness of the OHADA. In particular, the recently established OHADA National Commission could concentrate on disseminating the content of the regulations and guidelines adopted by the OHADA. Lawyers and business executives in Chad, including bankers, know little about the latest revisions to the general trade law and the law on guarantees adopted by the OHADA Council of Ministers. The revisions to the OHADA uniform acts on the law governing securities and the general trade law adopted in December 2010 constitutes a major development for loan guarantees.

57. Lending institutions have a strong preference for mortgages as collateral, despite constraints related to the difficulty in obtaining land titles and in foreclosing on mortgages. Land administration, in particular the cadastre, was not properly organized, resulting in delays and unreliability. The land tenure system and the organization of the land administration need to be improved, including establishing mortgages on future buildings, and facilitating acquisition of the title to the land after the mortgage loan is granted. The December 2010 revisions to the OHADA uniform acts aim, inter alia, to facilitate the constitution of collateral, expand the range of property eligible as security, provide national and regional advertising easily accessible to the public, and establish more flexible modalities for foreclosing mortgages or realizing collateral, particularly under arbitration. Under the reforms, the registration and enrolment requirement, a double formality that is both restrictive and costly, was discontinued. Now there is a single requirement to register in the commercial and credit register (Registre de Commerce et de Crédit Immobilier-RCCM). The registration of guarantees and companies, which is critical to the safety of commercial and banking activity, is unreliable because the data are, for the most part, manually managed and filed. The OHADA with the support of a committee of experts has initiated a program for modernization the RCCM, including computerizing its operations. This program if implemented rapidly should facilitate the functioning of the RCCM allowing for paperless procedures and, in particular, for setting up and conducting searches of collateral online. It would also make it possible to obtain reliable information on economic operators in Chad, and to have a more reliable account of their legal, judicial, and financial situation, should be taken into account in launching the modernization process.

58. The number of businesses registering with the N'Djamena RCCM every year is quite limited. Reportedly, in 2010, there were 1065 individual businesses registered and 533 corporations compared with 917 and 477, respectively in 2009. Regarding the 
registration of collateral securities, there were no more than 10 requests for registration of a pledge in N'Djamena in 2010. An RCCM with exclusive authority at the national level should be assigned responsibility for registering and publicizing collateral securities, as permitted under OHADA regulations. This decision would facilitate electronic registration and searches of collateral securities in the short run and would enhance the reliability of and access to information. The banks and notaries public should be able to perform the formalities of registering securities online at the RCCM website through subscriptions.

\section{A law on the treatment of troubled enterprises is imperative to ensure greater market security and to promote economic stability and growth in the OHADA zone.} Insolvency laws contribute to private sector development when they favor the continued existence of viable and operational enterprises while facilitating the liquidation of companies that have been irretrievably compromised. The continued operation of viable enterprises experiencing difficulties is the best approach for creditors and will improve their chances of collecting their debts. Although it was reported that not a single judicial recovery procedure had been filed with the commercial court in N'Djamena during the past three years, it is recommended that the treatment of troubled enterprises be improved through the effective participation of the Chadian government in the reform process being implemented under the OHADA Uniform Act on bankruptcy and the settlement of liabilities (AUPC). In parallel, the CEMAC is developing the crisis resolution framework for financial institutions and seeking exceptions to the AUPC, the OHADA bankruptcy law. 


\section{Appendix I. Risk Assessment Matrix}

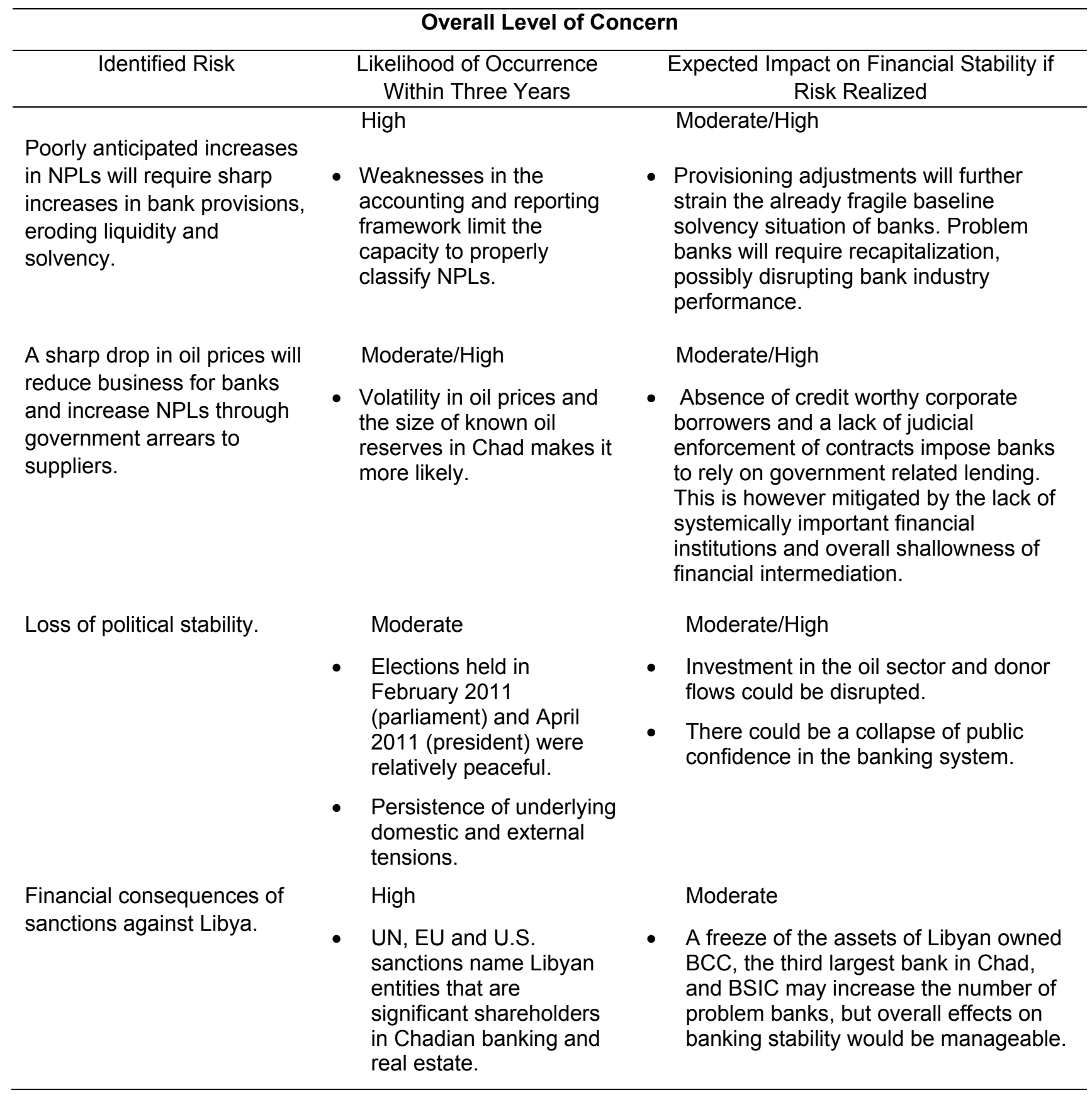


Appendix II. Indicators' Tables

Table 3. Macroeconomic and Financial Indicators (2009-16)

\begin{tabular}{|c|c|c|c|c|c|c|c|c|c|c|}
\hline & \multirow{2}{*}{$\begin{array}{l}2009 \\
\text { Est. }\end{array}$} & \multicolumn{2}{|c|}{2010} & \multicolumn{2}{|c|}{2011} & \multirow[t]{2}{*}{2012} & \multirow[t]{2}{*}{2013} & \multirow{2}{*}{$\frac{2014}{\text { ojections }}$} & \multirow[t]{2}{*}{2015} & \multirow[t]{2}{*}{2016} \\
\hline & & Proj. $^{1}$ & Est. & Proj. ${ }^{1}$ & $\begin{array}{l}\text { Rev. } \\
\text { Proj. }\end{array}$ & & & & & \\
\hline & \multicolumn{10}{|c|}{ (Annual percentage change, unless otherwise indicated) } \\
\hline \multicolumn{11}{|l|}{ Real economy } \\
\hline GDP at constant prices & -1.2 & 4.3 & 13.0 & 3.9 & 3.1 & 7.4 & 3.2 & 3.2 & 3.3 & 3.5 \\
\hline Oil GDP & -5.1 & 2.1 & 6.4 & -2.2 & -1.8 & 10.4 & -4.9 & -4.4 & -4.5 & -3.9 \\
\hline Non-oil GDP & 0.1 & 4.9 & 16.8 & 5.5 & 3.6 & 6.0 & 5.3 & 5.0 & 5.0 & 5.0 \\
\hline Consumer price index (period average) & -2.1 & 6.0 & -2.1 & 3.0 & 2.0 & 5.0 & 3.0 & 3.0 & 3.0 & 3.0 \\
\hline \multicolumn{11}{|l|}{ Oil prices } \\
\hline WEO (US\$/barrel) & 61.8 & 78.3 & 79.0 & 82.5 & 106.3 & 105.3 & 101.8 & 99.5 & 98.8 & 98.5 \\
\hline Chadian price (US $\$ /$ barrel $)^{2}$ & 55.5 & 68.3 & 73.6 & 72.5 & 99.8 & 98.8 & 95.3 & 93.0 & 92.3 & 92.0 \\
\hline Oil production (in millions of barrels) & 43.6 & 44.0 & 44.7 & 43.0 & 44.2 & 46.8 & 44.4 & 42.2 & 40.1 & 38.1 \\
\hline Exchange rate CFAF per US $\$$ (period average) & 471.0 & $\ldots$ & 494.4 & $\ldots$ & $\ldots$ & $\ldots$ & $\ldots$ & $\ldots$ & $\ldots$ & $\ldots$ \\
\hline \multicolumn{11}{|l|}{ Money and credit $^{3}$} \\
\hline Net foreign assets & -71.1 & -0.7 & 13.6 & 14.4 & 42.1 & 25.1 & $\ldots$ & $\ldots$ & $\ldots$ & ... \\
\hline Net domestic assets & 67.1 & 20.7 & 11.8 & -5.2 & -29.4 & -16.0 & $\ldots$ & $\ldots$ & $\ldots$ & ... \\
\hline Of which: net claims on central government & 68.3 & 16.1 & 5.0 & -8.3 & -33.1 & -19.6 & $\ldots$ & $\ldots$ & $\ldots$ & $\ldots$ \\
\hline Of which: credit to private sector & 5.3 & 4.6 & 8.4 & 3.6 & 3.7 & 3.6 & $\ldots$ & $\ldots$ & $\ldots$ & $\ldots$ \\
\hline Broad money & -4.0 & 20.0 & 25.4 & 9.2 & 12.7 & 9.1 & $\cdots$ & $\cdots$ & $\cdots$ & $\cdots$ \\
\hline Income velocity (non-oil GDP/broad money) & 4.5 & 4.1 & 4.3 & 4.1 & 4.3 & 4.3 & $\ldots$ & $\ldots$ & $\ldots$ & $\ldots$ \\
\hline \multicolumn{11}{|l|}{ External sector (valued in CFA francs) } \\
\hline Exports of goods and services, f.o.b. & -27.5 & 21.2 & 37.2 & 3.4 & 29.0 & -3.6 & -4.6 & -3.1 & -1.8 & -1.3 \\
\hline Imports of goods and services, f.o.b. & 20.5 & 14.1 & 46.3 & -5.6 & -13.9 & -27.3 & -3.3 & -0.1 & -3.3 & -3.4 \\
\hline Export volume & -7.9 & -8.3 & -4.9 & -3.3 & 1.0 & -3.4 & -3.7 & -3.6 & -3.6 & -3.5 \\
\hline Import volume & 27.5 & 16.8 & 49.9 & -17.0 & -10.2 & -21.7 & -7.8 & -4.0 & -5.5 & -5.4 \\
\hline Terms of trade & -44.9 & 24.9 & 41.6 & 4.0 & 24.0 & 0.2 & -1.5 & 0.0 & 1.5 & 1.9 \\
\hline Current account, including official transfers (in percent of GDP) & -18.3 & -33.1 & -34.6 & -26.1 & -23.9 & -16.9 & -11.7 & -11.0 & -10.1 & -9.7 \\
\hline Overall balance of payments (in percent of GDP) & -10.6 & 0.5 & 0.8 & 2.4 & 5.5 & 3.6 & 0.8 & 0.3 & 0.3 & 0.0 \\
\hline External debt (in percent of GDP) & 23.0 & 27.4 & 25.0 & 27.8 & 23.8 & 23.8 & 23.2 & 22.2 & 21.3 & 20.2 \\
\hline NPV of external debt (in percent of exports of goods and services) & 39.7 & 52.3 & 43.9 & 57.1 & 38.4 & 41.7 & 51.3 & 54.6 & 57.1 & 58.5 \\
\hline & \multicolumn{10}{|c|}{ (In percent of non-oil GDP, unless otherwise indicated) } \\
\hline \multicolumn{11}{|l|}{ Government finance } \\
\hline Revenue & 25.2 & 37.2 & 38.7 & 34.7 & 44.0 & 38.0 & 34.1 & 33.1 & 30.6 & 28.6 \\
\hline Of which: non-oil & 12.0 & 12.0 & 12.5 & 12.9 & 10.6 & 11.7 & 12.2 & 12.5 & 12.7 & 13.1 \\
\hline Expenditure & 46.1 & 49.7 & 49.9 & 36.3 & 42.1 & 36.1 & 35.7 & 34.1 & 32.8 & 32.4 \\
\hline Current & 29.7 & 33.5 & 29.6 & 22.6 & 25.0 & 20.1 & 20.2 & 19.1 & 18.3 & 17.9 \\
\hline Capital & 16.5 & 16.2 & 20.2 & 13.8 & 17.2 & 16.0 & 15.5 & 15.0 & 14.5 & 14.5 \\
\hline Non-oil primary balance (commitment basis, excl. grants) ${ }^{4}$ & -28.1 & -31.8 & -31.2 & -17.7 & -26.2 & -19.2 & -18.4 & -16.6 & -15.1 & -14.3 \\
\hline Overall fiscal balance (cash basis, excl. grants) & -20.8 & -10.6 & -9.3 & -1.0 & 3.9 & 0.7 & -1.3 & -1.0 & -2.1 & -3.5 \\
\hline Total debt (in percent of GDP) ${ }^{5}$ & 30.5 & 34.2 & 32.6 & 32.4 & 29.5 & 27.9 & 27.8 & 25.8 & 24.5 & 24.6 \\
\hline Of which: domestic debt & 7.5 & 6.8 & 7.6 & 4.6 & 5.7 & 4.1 & 4.6 & 3.5 & 3.1 & 4.4 \\
\hline & \multicolumn{10}{|c|}{ (In percent of GDP) } \\
\hline \multicolumn{11}{|l|}{ Investment and saving } \\
\hline Investment & 36.9 & 36.8 & 37.9 & 34.7 & 28.9 & 19.7 & 18.9 & 18.0 & 18.0 & 18.2 \\
\hline Government & 8.8 & 10.2 & 12.3 & 8.8 & 11.2 & 11.0 & 11.1 & 11.1 & 11.0 & 11.3 \\
\hline Private sector & 28.1 & 25.6 & 25.6 & 24.9 & 17.8 & 8.7 & 7.8 & 6.9 & 7.1 & 7.0 \\
\hline Of which: oil sector & 11.4 & 24.0 & 21.2 & 17.1 & 13.0 & 3.7 & 2.6 & 1.5 & 1.5 & 1.3 \\
\hline Saving & 18.6 & 3.7 & 3.3 & 8.6 & 5.1 & 2.8 & 7.3 & 7.0 & 7.9 & 8.5 \\
\hline Government & 0.6 & 3.9 & 7.2 & 9.4 & 14.2 & 14.7 & 12.5 & 12.9 & 12.0 & 11.1 \\
\hline Private sector & 18.0 & -0.2 & -3.9 & -0.8 & -9.1 & -11.9 & -5.2 & -5.9 & -4.0 & -2.6 \\
\hline Memorandum items: & & & & & & & & & & \\
\hline Nominal GDP (in billions of CFA francs) & 3,344 & 3,758 & 4,230 & 4,032 & 4,476 & 4,537 & 4,689 & 4,890 & 5,119 & 5,369 \\
\hline Of which: non-oil GDP & 2,138 & 2,369 & 2,584 & 2,587 & 2,912 & 3,128 & 3,357 & 3,604 & 3,875 & 4,171 \\
\hline
\end{tabular}

Sources: Chadian authorities; and IMF staff estimates and projections.

${ }^{1}$ IMF Country Report No. 10/196; Chad--Staff Report for the 2010 Article IV Consultation.

${ }^{2}$ Chadian oil price is WEO price minus quality discount.

${ }^{3}$ Changes as a percent of broad money stock at beginning of period.

${ }^{4}$ Defined as the total revenue excluding grants and oil revenue, minus total expenditure excluding net interest payments and foreign-financed investment.

${ }^{5}$ Central government. 
Table 4. Chad : Banking Sector Soundness Indicators

\begin{tabular}{lrrrrr}
\hline & 2007 & 2008 & 2009 & 2010 & 2011 \\
\hline & & & & & Mar. \\
Capital Adequacy & & & & & \\
Regulatory capital / Risk-weighted assets & 11.1 & 13.3 & 12.1 & 6.7 & 9.8 \\
Tier 1 capital/ Risk-weighted assets 1/ & 10.0 & 13.1 & 13.5 & 11.3 & 9.1 \\
& & & & & \\
Asset Quality & & & & & \\
Gross nonperforming oans/Gross banking loans & 11.2 & 8.0 & 10.4 & 12.1 & 9.6 \\
Provisions / Nonperforming loans & 84.4 & 70.2 & 64.6 & 73.5 & 67.3 \\
Net nonperforming loans/Gross banking loans & 1.7 & 2.4 & 3.7 & 3.2 & 3.1 \\
& & & & & \\
Profitability & & & & & \\
Return on assets & 2.7 & 3.9 & 1.3 & 3.7 & $\ldots$ \\
Return on equity & 26.3 & 36.4 & 11.4 & 39.4 & $\ldots$ \\
& & & & & \\
Liquidity & & & & & \\
Liquid assets / Total assets & 28.3 & 23.9 & 19.9 & 24.5 & 25.0 \\
Liquid assets / Demand deposits & 66.3 & 82.4 & 85.2 & 73.8 & 82.7 \\
\hline
\end{tabular}

Source: BEAC/COBAC.

$1 /$ Data reflect 8 banks in Chad. Due to the supervisory charges on some banks, tier 1 capital is larger than regulatory capital for 2009 and 2010. 


\section{Appendix III. Stress Test Methodologies and Results}

\section{The stress tests applied shocks to end-December 2010 data of six individual} banks. ${ }^{10}$ Two subgroups of banks were identified: (i) foreign banks (owned by banks or individuals outside Chad represents 65 percent of assets); and (ii) state-owned banks (35 percent of assets). ${ }^{11}$ The mission simulated extreme but plausible shocks in line with the economic structure of Chad. The mission also modified the baseline value of the bank solvency ratio to better adjust for the under-provisioning of NPLs as result of the poor quality of the bank data submitted to the BEAC. ${ }^{12}$

\section{The stress tests carried out by the mission suggest that the Chadian banking} system is generally vulnerable to a wide range of risks, and particularly vulnerable to credit risk (Table 6). However, even with the magnitude of the simulated shocks, the capital requirements remained under 1 percent of GDP (Table 7), which is a clear reflection of the low significance of financial intermediation in Chad. Eight shocks were tested based on three broad categories of credit risk: (i) sectoral and exposure risk; (ii) overall credit risk; and (iii) credit risk related to public finance (Table 5).

\section{Table 5. Stress Test-Credit Risk}

\begin{tabular}{llc}
\hline & \multicolumn{1}{c}{ Shocks } & Provisioning \\
\hline Sectoral risk concentration & Default by the largest individual exposure & $100 \%$ \\
& Non-extracative industry sector & $100 \%$ \\
& Trade sector & $100 \%$ \\
& Construction and public work sector & $100 \%$ \\
Overall credit risks & Downgrade NPLs by one category & Current average rate \\
& 50 percent increase in total NPLs & Current average rate \\
& Default on bank credit to the government and to & $100 \%$ \\
& public enterprises & $100 \%$ \\
\hline
\end{tabular}

Source: IMF staff estimates.

\section{The major risk factor lies in the strong concentration of individual loans,} reflecting the widespread breach of numerous prudential rules. While, regulations require that risk be limited to 45 percent of capital (a level that seems generous in comparison with international practices), the largest individual exposure represents, on

\footnotetext{
${ }^{10}$ Two banks under provisional administration or in the process of restructuring in connection with a change in shareholders were excluded.

${ }^{11}$ None of the banks in Chad are majority owned by local private shareholders.

${ }^{12}$ A large proportion of NPLs will likely not be recovered and should have higher weighted provisions in principle and in accordance with COBAC's regulations.
} 
average, 100 percent of bank capital. ${ }^{13}$ Consequently, default by the largest individual borrower of each bank would have a serious impact on the banking system (only one bank would have enough equity to meet the statutory minimum, as opposed to five before the shock). The government or public enterprises with government-backed liabilities, large private or foreign companies and often their shareholders as well, or companies of questionable origin are the main sources of individual borrower risk.

\section{Default by the Chadian government would have a substantial effect on the} banks' portfolio. Default by the Chadian government on 50 percent of public debt service would cause the average solvency ratio of banks to drop from 8.2 percent to -7.3 percent, with a marked impact on the banks with significant public sector ownership. If the default were compounded by salary arrears, there would, in principle, further portfolio and solvency problems. ${ }^{14}$ The test also simulated a shock of 50 percent increase in government's NPLs which would bring banking system's solvency ratio down from 8.2 to 7 percent, below the minimum requirement.

63. A sharp decline in the quality of bank credit, all sectors combined, would have a major impact on banks' solvency. If, hypothetically, overdue debts were downgraded by one category, the impact on the solvency ratios would be limited (less than 1 percentage point on average). However, an increase of 50 percent in NPLs would result in a significant deterioration in bank solvency, with the average solvency ratio moving to 2.3 percent.

\section{Although economic activity is concentrated in a few sectors, this does not} necessarily mean that the banks are highly vulnerable to sectoral shocks given the low level of bank credit relative to real economic activity. Adverse developments in the oil sector, for example (an untested shock), would have a largely indirect effect on the banks as a result of the knock-on effects of the poor performance of public finance on certain enterprises or households receiving bank loans. However, enterprises engaged in petroleum mining and other areas generally have relatively limited financial relations with the Chadian banks.

65. A change in the euro/CFAF or euro/dollar exchange rate was simulated. Four shocks were tested: (i) a 40-percent depreciation of the CFAF relative to the euro; (ii) a 40-percent appreciation of the CFAF relative to the euro; (iii) a 40-percent depreciation of the euro vis-à-vis the dollar; and (iv) a 40-percent appreciation of the euro relative to the dollar. The Chadian banks are sensitive to an appreciation in the CFA franc relative to the euro given the sizable net external positions of the banks vis-à-vis the euro.

66. The effects of an increase in interest rates on the value of bank portfolios were simulated. As there is a sizable cumulative maturity mismatch given the dominant share of short-term liabilities, the impact of an increase in interest rates on portfolio valuation would

\footnotetext{
${ }^{13}$ This estimate does not take account prudential regulations and the very favorable weighting that can be given to some major risks, such as that of Coton Chad and the sugar company.

${ }^{14}$ Arrears in the payment of civil servants' salaries is often an adjustment variable and, in Chad, civil servants represent the largest share of the banking population.
} 
be significant; while the impact on the average profitability of the banks would be even greater (the average return on assets would drop from 2 percent to 1 percent). However, it is difficult to gauge which of the BEAC rates would ultimately have the greatest impact on bank balance sheets as there are no effective monetary policy transmission instruments.

\section{Table 6. Summary of Stress Tests}

(In percent unless otherwise indicated)

\begin{tabular}{|c|c|c|c|c|c|c|c|c|c|}
\hline & & & & & & & $\begin{array}{c}\text { State- } \\
\text { Owned }\end{array}$ & Foreign & Total \\
\hline & Bank $1^{1}$ & Bank 2 & Bank 3 & Bank 4 & Bank 5 & Bank 6 & Banks $^{2}$ & Banks & Banks $^{3}$ \\
\hline Capital Adequacy ratio before the shocks & -9.1 & 22.6 & 16.1 & 12.1 & 15.3 & 38.1 & 3.8 & 17.2 & 12.8 \\
\hline Adjus ted capital adequacy ratio before the shocks ${ }^{4}$ & -15.0 & 20.4 & 13.4 & 1.9 & 10.8 & 38.1 & -0.6 & 12.6 & 8.2 \\
\hline \multicolumn{10}{|l|}{ Capital adequacy ratio after shocks } \\
\hline \multicolumn{10}{|l|}{ A. Credit Risk } \\
\hline Default of the largest individual exposure & -18.0 & 4.5 & -2.8 & -16.9 & 4.7 & 15.0 & -9.7 & -1.5 & -4.3 \\
\hline Public Sector & -18.0 & 4.5 & -2.8 & -16.9 & 4.7 & 15.0 & -9.7 & -1.5 & -4.3 \\
\hline Private Sector & -19.5 & 18.4 & 11.3 & -8.3 & 8.7 & 38.1 & -4.0 & 9.3 & 4.9 \\
\hline Increase of $50 \%$ of all nonperforming loans & -27.8 & 18.4 & 10.5 & -10.0 & 4.6 & 38.0 & -8.1 & 7.4 & 2.3 \\
\hline Downgrade of NPLs by one category & -15.3 & 20.4 & 13.0 & 1.0 & 10.4 & 38.1 & -0.7 & 12.2 & 7.9 \\
\hline Default of $50 \%$ of public sector loans & -18.4 & 19.8 & 12.6 & 1.7 & 9.2 & 38.1 & -2.7 & 11.7 & 7.0 \\
\hline \multicolumn{10}{|l|}{ Sectoral shocks } \\
\hline Non-extractive industries sector & -15.0 & 20.4 & 13.4 & -0.8 & 9.1 & 38.1 & -0.6 & 11.5 & 7.5 \\
\hline Trade sector & -15.0 & 20.4 & 13.0 & 0.4 & 10.8 & 38.1 & -0.6 & 12.1 & 7.9 \\
\hline Buildings and public works sector & -15.0 & 20.4 & 13.3 & 1.4 & 10.2 & 38.1 & -0.6 & 12.2 & 8.0 \\
\hline \multicolumn{10}{|l|}{ B. Exchange rate risk } \\
\hline $40 \%$ depreciation relative to the dollar & -14.6 & 20.4 & 13.2 & 2.9 & 10.8 & 38.1 & -0.3 & 12.7 & 8.4 \\
\hline $40 \%$ appreciation relative to the dollar & -15.4 & 20.4 & 13.6 & 1.0 & 10.8 & 38.0 & -0.8 & 12.4 & 8.1 \\
\hline $40 \%$ depreciation relative to the euro & -15.7 & 16.5 & 25.5 & 7.3 & 11.2 & 43.6 & -2.6 & 18.7 & 11.7 \\
\hline $40 \%$ appreciation relative to the euro & -14.3 & 24.3 & 1.3 & -3.5 & 10.3 & 32.6 & 1.5 & 6.4 & 4.8 \\
\hline \multicolumn{10}{|l|}{ C. Interest rate risk } \\
\hline Increase in interest rates of loans by 500 basis points & -13.7 & 18.1 & 6.3 & 0.0 & 8.2 & 50.4 & -0.8 & 10.0 & 6.4 \\
\hline Average return on assets (before shock) & -0.3 & 3.1 & 4.4 & 1.8 & 2.4 & -10.4 & 0.7 & 2.4 & 1.9 \\
\hline Average return on assets (after shock) & -0.6 & 1.9 & 2.5 & 1.0 & 1.4 & -9.2 & 0.1 & 1.2 & 0.9 \\
\hline D. Liquidity risk & Day 1 & Day 2 & Day 3 & Day 4 & Day 5 & Day 6 & & & \\
\hline Number of banks in critical liquidity situation ${ }^{56}$ & 0 & 1 & 1 & 1 & 1 & 1 & & & \\
\hline State banks & 0 & 1 & 1 & 1 & 1 & 1 & & & \\
\hline Foreign Banks & 0 & 0 & 0 & 0 & 0 & 0 & & & \\
\hline \multicolumn{10}{|l|}{ E. Combination of scenario shocks } \\
\hline Shock interest rate + Credit Default State & -17.1 & 17.4 & 5.5 & -0.2 & 6.6 & 50.4 & -2.9 & 9.1 & 5.2 \\
\hline Appreciation against the euro credit default + state & -17.7 & 23.7 & 0.5 & -3.7 & 8.8 & 32.6 & -0.6 & 5.6 & 3.6 \\
\hline Shock interest rate + increase in all doubtful & -26.6 & 16.1 & 3.3 & -11.8 & 2.0 & 50.4 & -8.3 & 4.8 & 0.5 \\
\hline Increase in total nonperforming loans + credit default state & -31.3 & 17.8 & 9.7 & -10.2 & 3.0 & 38.0 & -10.2 & 6.6 & 1.1 \\
\hline
\end{tabular}

Source: IMF staff estimates.

1. This bank has negative regulatory capital after a capital charge for violating prudential norms, related to its significant liabilities to individuals and corporations connected to the bank's personnel and its board of directors. During the mission, COBAC was unable to confirm whether the situation had been officially resolved.

2. The banks with majority Libyan shareholdings are also included.

3. Two banks in the process of restructuring or provisional administration were excluded from the tests.

4. This ratio was adjusted to compensate for underreporting and under-provisioning of NPLs, in compliance with COBAC regulations.

5. A critical liquidity situation is defined as a situation in which liquid assets become less-than-liquid liabilities.

6. The results would be comparable with an intensified run on deposits in Libyan banks. 
67. Liquidity shocks were also applied by simulating a run on the banks for 10 consecutive business days and providing the banks with no recourse to emergency funds (from other banks or from the BEAC). The results show that all banks except one would be able to contain the effects of the liquidity drain. The daily rates of deposit flight were calibrated on the basis of historical data observed since the start of the political events in Libya in early-2011. At first glance, it seems that the events in Libya had a marked but limited impact on one or two banks. However, it is very likely that the deterioration in the political situation would have a heightened impact on liquidity.

Table 7. Cost of Recapitalization-Default of the Largest Individual Borrower

\begin{tabular}{lrrr}
\hline & $\begin{array}{c}\text { Capital Needed to } \\
\text { Meet the Regulatory } \\
\text { Minimum Requirement } \\
\text { (In millions of CFAF) }\end{array}$ & $\begin{array}{c}\text { Capital } \\
\text { Requirement (In } \\
\text { percent of GDP) }\end{array}$ & $\begin{array}{c}\text { Deposit of } \\
\text { Negative Capital } \\
\text { Banks (In } \\
\text { percent of GDP) }\end{array}$ \\
\hline Bank1 & 11,144 & 0.29 & 1.8 \\
Bank2 & 1,280 & 0.03 & $\ldots$ \\
Bank3 & 5,592 & 0.15 & 2.1 \\
Bank4 & 6,883 & 0.18 & 1.0 \\
Bank5 & 1,789 & 0.05 & $\ldots$ \\
Bank6 & $\ldots$ & $\ldots$ & $\ldots$ \\
Total banks & 26,688 & 0.70 & 4.8 \\
\hline
\end{tabular}

Source: IMF staff estimates.

1/ Private sector deposits. 